\title{
Antimicrobial effect of calcium hydroxide as endo intracanal dressing on Streptococcus viridans
}

\author{
Nanik Zubaidah \\ Department of Conservative Dentistry \\ Faculty of Dentistry Airlangga University \\ Surabaya - Indonesia
}

\begin{abstract}
Calcium hydroxide had been used as the intra-canal dressing in endodontic treatment due to its high alkaline and antimicrobial capacity. It can also dissolve the necrotic tissue, prevent dental root resorbtion and regenerate a new hard tissue. The aim of this study was to determine the concentration of calcium hydroxide which had the highest antimicrobial effect on Streptococcus viridans. Samples were divided into 5 groups; each group consisted of 8 samples with different concentration of calcium hydroxide. Group I: 50\%, group II: 55, Group III: 60\%, Group IV: 65\%, Group V: 70\%. The antimicrobial testing was performed using diffusion method against Streptococcus viridans. The result of susceptibility test was showed by the inhibition zone diameter which measured with caliper (in millimeter). We analyzed the data using One-Way ANOVA test with significant difference 0.05 and subsequently LSD test. The study showed that calcium hydroxide with concentration $60 \%$ has the highest antimicrobial effect.
\end{abstract}

Key words: calcium hydroxide, Streptococcus viridans, antimicrobial effect

Correspondence: Nanik Zubaidah, c/o: Departemen Konservasi Gigi, Fakultas Kedokteran Gigi Universitas Airlangga. Jln. Mayjend. Prof. Dr. Moestopo no. 47 Surabaya 60132, Indonesia.

\section{INTRODUCTION}

Since calcium hydroxide applied in dentistry, it has been used for many purposes such as cavity liner; direct and indirect pulp capping; apexification; root resorption prevention; iatrogenic perforation; improvement in cavity base and root canal wall; treatment of horizontal and vertical root fracture; main substance of root canal paste (sealer) and root canal (filler); and irrigation material. ${ }^{1-3}$

Along with science development and modern technology, calcium hydroxide as intracanal dressing has been introduced in modern endodontic treatment to reach sterile root canal. It is due to the capability of calcium hydroxide to solve necrotic tissue; stimulate odontoblast activity and capable penetrate into accessories root canal and dentinal tubule so it would lower permeability of dentinal surface; capable to neutralize acid condition produced by osteoclast activity therefore it could prevent eliminated tissue from further damage; due to presence of calcium ion it could promote excessive exudates to dry and make permeability of capillary blood vessel decrease; and finally calcium hydroxide has very effective antimicrobial effect in endodontic treatment. ${ }^{1,4}$

Grossman et al., ${ }^{5}$ suggested that a medicine which is used as intracanal dressing must fulfill some requirements such as: germicide and fungicide; non irritated substance on periapical tissue; stable in solution; long antimicrobial effect; presence of blood, serum and derivate of tissue protein do not decrease the effect; low surface tension; does not change tooth color.
Tronstad et al., ${ }^{6}$ suggested that placing calcium hydroxide into root canal would increase $\mathrm{pH}$, contribute alkalis environment in the adjacent tissue by diffusing hydroxyl ion through dentinal tubule. Increasing $\mathrm{pH}$ would make calcium hydroxide bactericidal and inhibit osteoclast activity. When calcium hydroxide is solved in sterile aquabidest, it would decompose in calcium ion $\left(\mathrm{Ca}^{2+}\right)$ and hydroxyl ion $\left(\mathrm{OH}^{--}\right)$. The occurrence of hydroxyl ion in solution would make the environment alkalis $(\mathrm{pH}=12.5$ at $37^{\circ} \mathrm{C}$ ) and destroy bacterial membrane. That condition will killed bacteria.,

According to Siquira and Lopes ${ }^{8}$ the antibacterial effect of calcium hydroxide used as intra-canal dressing is due to its ability to destroyed cytoplasmic membrane cell of bacterial, to denaturized protein and destroyed DNA of bacteria. The most common bacteria found in infected root canal is gram positive bacteria such as: Streptococcus viridans including Streptococcus hemolyticus, Lactobacillus and Staphylococcus and followed by gram negative bacteria and some fungi group. ${ }^{8,9}$ Grossman et al. ${ }^{5}$ found the domination of Streptococcus $\alpha$ Hemolitycus such as Streptococcus viridans (63\%), Staphylococcus albus (17\%), Dipteroid bacilli (6.5\%), Staphylococcus aureus, Bacillus proteus, Bacillus coli. Saifudin ${ }^{10}$ found Streptococcus $\alpha$ hemolyticus $(76.6 \%)$ and anaerobe obligate bacteria $(23.4 \%)$ infected root canal.

In early 1900, a theory was found on focus infection using intracanal dressing with strong antimicrobial effect for root canal treatment. It contributes sterile root canal and periapical tissue and prevented the possibility of 
spreading dangerous bacteria into the body. ${ }^{6}$ Grossman et al. ${ }^{5}$ and Suzuki et al. ${ }^{11}$ stated that intracanal dressing could destroy pathogenic bacteria and kill microbial flora of infected root canal.

In general the clinical use of the $50 \%$ calcium hydroxide (50 gram calcium hydroxide powder in $100 \mathrm{ml}$ sterile aquabidest) is based on factory procedure. ${ }^{12}$ Hosoya et al. ${ }^{2}$ and Estrela ${ }^{13}$ used $44 \%$ and $38 \%$ calcium hydroxide with $\mathrm{pH}=11.24$ in their study to examine calcium ion $\left(\mathrm{Ca}^{2+}\right)$ and hydroxyl ion $\left(\mathrm{OH}^{-}\right)$release in the adjacent apical of root canal for 3 days. Sjogren et al. ${ }^{14}$ stated that calcium hydroxide paste is still effective as long as it is in root canal and shows antimicrobial force for seven days. Grossman et al. ${ }^{5}$ reported that calcium hydroxide is strong disinfectant in root canal. In this study, pure calcium hydroxide was used not only because its cost is relatively cheap but also because it is availability. It is expected that pure calcium hydroxide would be able to be applied as intracanal dressing in endodontic treatment. The optimum concentration of calcium hydroxide as intra-canal dressing which has highest antimicrobial effect on Streptococcus viridans is still need to be studied further.

The purpose of this study was to determine the concentration of calcium hydroxide which has optimal antimicrobial effect against Streptococcus viridans. The advantage of this study is to determine concentration of calcium hydroxide applied as intracanal dressing, so optimal endodontic treatment could also be reached.

\section{MATERIAL AND METHOD}

The study used the post test only controlled group design. The study was done at Dentistry and Oral Health Department of Dentistry Faculty, Airlangga University and antimicrobial test was done in microbiology laboratory of Dr. Soetomo General Hospital, Surabaya. The materials were pure calcium hydroxide powder (M2047, Merck Darmstad, Germany), sterile aquabidest (Kimia Farma), Media Brain Heart Infusion (BHI), Media chocolate agar, Normal saline ( $\mathrm{NaOCl} 0.85 \%)$, Streptococcus viridans (isolated from the patient).

\section{Calcium hydroxide paste preparation}

Calcium hydroxide paste was made by mixing calcium hydroxide powder with sterile aquabidest with concentration of $50 \%, 55 \%, 60 \%, 65 \%$, and $70 \%$ until paste was formed. The mixture was made in appendorf tube, after mixed using sterile spatel cement for one minute the mixture was homogenized with vortex for 30 seconds. ${ }^{13}$

\section{Isolation of Streptococcus viridans}

Streptococcus viridans was isolated from the patient's maxillary anterior teeth with the diagnosis of necrotic pulpa and periapical lesion. The procedure was done as follows; the working region was isolated by rubber dam and $70 \%$ alcohol was applied at the surface's tooth. Cavity entrance was made using sterile round bur and removed the pulp wall. Sterile paper point was inserted into root canal for one minute, and then paper point was put into Brain Heart Infusion (BHI) and incubated in $37^{\circ} \mathrm{C}$ for 24 hours. The bacteria culture was re-inoculated by spreading it with ose into blood agar media. After $37^{\circ} \mathrm{C}$ incubation for 24 hours, the bacterial growth was examined using light microscope. The bacteria was re-cultured using chocolate agar plate and incubated $37^{\circ} \mathrm{C}$ for 24 hours to determine coccus gram positive bacterial growth (chain form, $\alpha$ hemolytic). The identification was done by gram staining.

\section{Antibacterial examination}

Suspension was done by taking colonies of Streptococcus viridans and its culture media using ose, and then mixed by normal saline $(\mathrm{NaCl} 0.85 \%)$ until turbidity equal to standard Mc. Farland 0.5. One $\mathrm{ml}$ of $\mathrm{S}$. viridans suspension was taken and put into petridish containing Muller Hinton agar media and spread using sterile spreader. Wells were made at the surface of agar media by placing platinum ring with diameter of $6 \mathrm{~mm}$ and $9 \mathrm{~mm}$ height. Twenty five $\mu \mathrm{l}$ of Calcium Hydroxide with concentration of $50 \%$ (group I), 55\% (group II), 60\% (group III), 65\% (group IV), $70 \%$ (group V) were put into the wells in Muller Hinton agar media using pippete and incubated at $37^{\circ} \mathrm{C}$ for 24 hours. The inhibition zone was measured using caliper (0.5 accuracy; in millimeter). ${ }^{16}$

\section{RESULT}

The mean and standard deviation of inhibition zone for $50 \%, 55 \%, 60 \%, 65 \%$, and $70 \%$ calcium hydroxide against Streptococcus viridans showed on table 1 and figure 1. The result showed that $60 \%$ of calcium hydroxide had the highest inhibition zone comparing to other groups.

Table1. The mean and standard deviation of inhibition zone calcium hydroxide in various concentration against Streptococcus viridans ( $\mathrm{mm})$

\begin{tabular}{cccl}
\hline Concentration & $\mathrm{N}$ & \multicolumn{1}{c}{$\overline{\mathrm{X}}$} & \multicolumn{1}{c}{$\mathrm{SD}$} \\
\hline Group I 50\% & 8 & 14.6250 & 1.1877 \\
Group II 55\% & 8 & 14.8750 & 1.6421 \\
Group III 60\% & 8 & 15.7500 & 1.4880 \\
Group IV 65\% & 8 & 13.1250 & 1.260 \\
Group V 70\% & 8 & 11.350 & 1.1877 \\
\hline
\end{tabular}

Note: $\mathrm{N}=$ Number of samples, $\overline{\mathrm{X}}=$ Mean of inhibition zone, $\mathrm{SD}=$ Standard deviation

Statistical analysis using One Direction ANOVA test with significance level $p=0.05$ was done to determine the difference of inhibition zone of calcium hydroxide against Streptococcus viridans. The statistical result showed that there was a significant difference of inhibition zone of calcium hydroxide in various concentration against Streptococcus viridans $(\mathrm{p}<0.05)$. Least Significant 
Table 2. The result of LSD test in diameter of inhibition zone of calcium hydroxide in various concentration against Streptococcus viridans

\begin{tabular}{lccccc}
\hline \multicolumn{1}{c}{ Concentration } & Group I & Group II & Group III & Group IV & Group V \\
\hline Group I & --- & 0.712 & 0.102 & $0.032^{*}$ & $0.000^{*}$ \\
Group II & & --- & 0.201 & $0.013^{*}$ & $0.000^{*}$ \\
Group III & & --- & $0.000^{*}$ & $0.000^{*}$ \\
Group IV & & & -- & $0.013^{*}$ \\
Group V & & & & -- \\
\hline
\end{tabular}

*) significant difference $(\mathrm{p}<0.05)$

$\square 50 \% \square 55 \% \square 60 \% \square 65 \% \square 70 \%$

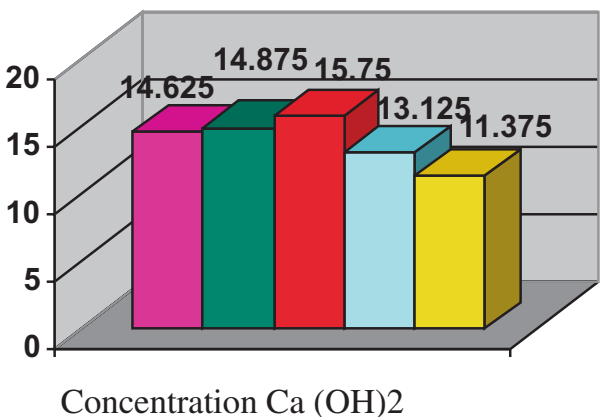

Figure 1. Mean of inhibition zone for $50 \%, 55 \%, 60 \%, 65 \%$, and $70 \%$ calcium hydroxide against Streptococcus viridans.

Difference (LSD) test was done to determine the difference of diameter of inhibition zone (table 2).

\section{DISCUSSION}

An intra-canal dressing is necessarily given prior to root canal preparation in endodontic treatment to sterilize root canal either from anaerobe or facultative anaerobe bacteria. The dominant bacterial found in root canal are Streptococcus viridans which is facultative anaerobe. Calcium hydroxide used as an intracanal dressing in endodontic treatment because it has an alkalis $\mathrm{pH}$ (12.5) and high anti microbial effect. ${ }^{5,17,22}$ The antimicrobial effect of material or drugs can be examined by sensitivity tests against bacteria, such as dilution or diffusion method.

Agar diffusion method was chosen based on several reasons. First, this method could be used for activity evaluation of antimicrobial medicine which the concentration had been determined. Second, the time needed to analyze the inhibition zone was relatively short. Third, the equipments were simple and easily obtained. Fourth, the cost was relatively inexpensive, and the most important was the method could determine the bactericide effect of medicine by observing inhibition zone occurred in agar media. This method is generally used to examine anti microbial effect of materials including material of endodontic treatment. ${ }^{17,18}$
Di Fiore, ${ }^{19}$ Siqueira and Uzeda, ${ }^{18}$ Gomes et al. ${ }^{20}$ stated that the result of anti microbial test using agar diffusion method depends on several aspects: the size of material molecule, solubility and diffusibility of material in agar media, medicine sensitivity, source of bacterial (strain of species colony), the number of inoculated bacteria, $\mathrm{pH}$ of substrate in plate, agar viscosity, condition of agar storage, incubation time and metabolic activity of bacteria. The higher the solubility and diffusibility of material against the media the bigger inhibition zone will be.

Fifty percent of calcium hydroxide is the lowest concentration. The result of previous study showed that the viscosity of calcium hydroxide mixed with sterile aquabidest similar to paste. In this case, it is similar with clinical use in which the ratio between calcium hydroxide powder and sterile aquabidest with $50 \%$ concentration. Gomes et al. ${ }^{20}$ using $50 \%$ concentration of calcium hydroxide paste proved that Gram negative anaerobe bacteria was more sensitive to calcium hydroxide than Gram positive anaerobe facultative bacteria.

Sixty percent concentration of calcium hydroxide showed mean of inhibition zone was $15,7500 \mathrm{~mm}$ (Table 1) which the highest antimicrobial effect comparing to the other groups. It might due to ion hydroxyl released $\left(\mathrm{OH}^{-}\right)$from calcium hydroxide. Ion hydroxyl $\left(\mathrm{OH}^{-}\right)$is highly free radical oxidant shows strong reactivity against bacterial cell. ${ }^{21}$ Effect of ion hydroxyl $\left(\mathrm{OH}^{-}\right)$is very reactive and quickly combines itself with lipid, protein and nucleate acid resulting lipid peroxides. It would increase membrane permeability of bacterial cells, and followed by protein denaturation, inactivating enzyme and DNA destruction which kill the bacteria. ${ }^{1,12}$ In this concentration calcium hydroxide has not reached the saturation point so calcium hydroxide is still capable to diffuse into Muller Hinton agar culture media which has been exposed by Streptococcus viridans.

Table 2 showed the antimicrobial test result of calcium hydroxide against Streptococcus viridans. Calcium hydroxide $55 \%$, and $60 \%$ concentration compare to group $50 \%$, $60 \%$ concentration compare to $55 \%$, did not show significant difference. It might due to viscosity of the mixture and the number of released hydroxyl ion was the same. In $65 \%$ concentration compare to $50 \%, 55 \%$, and $60 \%$ concentration of calcium hydroxide, and also $70 \%$ concentration comparing to $50 \%, 55 \%, 60 \%, 65 \%$ calcium 
hydroxide showed significant difference in inhibition zone against Streptococcus viridans. It might due to the viscosity of calcium hydroxide powder and sterile aquabidest has reached saturation point in $65 \%$ and $70 \%$ concentration, consequently, hydroxyl ion is difficult to release into agar media resulting the decrease of number of hydroxyl ion and small inhibition zone. The diffusibility and solubility of calcium hydroxide in agar media was very low due to high viscosity of material. Safavi and Nakayama ${ }^{7}$ suggested that the effect of water insoluble solvent would decrease the affectivity of calcium hydroxide. It is also proved by Suzuki ${ }^{11}$ by mixing calcium hydroxide and pure glycerin or propylene glycol (including calcium hydroxide vehicle). Both materials are non-polar therefore it does not show inhibition zone of bacteria. Since the solution has reached saturation point, so, hydroxyl ion $\left(\mathrm{OH}^{-}\right)$can not diffuse into agar culture media. The number of hydroxyl $\left(\mathrm{OH}^{-}\right)$which has been released will be less and the anti microbial effect will decrease. There is other factor such as buffer capacity of culture media which lowering the $\mathrm{pH}$. It makes the antimicrobial of calcium hydroxide reduce. ${ }^{23,26}$ The study showed that calcium hydroxide with $60 \%$ concentration showed the highest antimicrobial effect compared to calcium hydroxide with $50 \%, 55 \%, 65 \%$, and $70 \%$ concentration.

\section{REFERENCES}

1. Estrela C. Calcium hydroxide: study based on scientific evidences. J Appt Oral Sci 2003; 11(4):269-82.

2. Hosoya N, Takahashi G, Arai T, Nakamura J. Calcium concentration and $\mathrm{pH}$ of periapical environment after applying calcium hydroxide into root canals in vitro. J Endod 2001; 27(5):343-6.

3. Solak H, Oztan MD. The $\mathrm{pH}$ change of four different calcium hydroxide mixture used for intracanal medication. J Oral Rehab 2003; 30:436-9.

4. Leonardo MR, Sielveira FF. Calcium hydroxide root canal dressing. Histopathological evaluation of periapical repair at different time periods. J Braz Dent 2002; 13:17-22.

5. Grossman LI, Oliet S, Del Rio CE. Ilmu endodontik dalam praktek. Abyono R, editor. Cetakan I. Jakarta: Penerbit Buku Kedokteran EGC; 1995. p. 248-50, 256.

6. Tronstad L, Andreasen JO, Hasselgren G, Kristerson L, Riis I. pH change in dental tissue alter root canal filling with calcium hydroxide. J Endod 1981; 7:17.

7. Safavi $K$ and Nakayama TA. Influence of mixing vehicle on dissociation of calcium hydroxide in solution. J Endod 2000; 26:649-52.
8. Siqueira JF, Lopes HP. Mechanisms of antimicrobial activity of calcium hydroxide: a critical review. J Intern Endod 1999; 32:361-9.

9. Pitt Ford TR. Endodontic in clinical practice. London: United Medical and Dental Schools, University of London, UK; 1997. p. 108-9.

10. Saifuddin I. Khasiat dan efek iritasi antiseptik poliantibiotika dengan metronodazol sebagai obat sterilisasi saluran akar. Surabaya: Penelitian Laboratorium; 1986. p. 13-14.

11. Suzuki K, Higuchi N, Horiba N, Matsumoto T, Nakamura H Antimicrobial effect of calcium hydroxide on bacteria isolated from infected root canals. J Conservative Dentistry in Japan 1999; 35:43-47.

12. Siqueira JF, Uzeda M. Influence of different vehicle on the antibacterial effect of calcium hydroxide. J Endod 1998; 24(10):663.

13. Estrela C, Pimenta FC, Ito Yoko I, Bammann L. In vitro determination of direct antimicrobial effect of calcium hydroxide. J Endod 1998; 24(1):15-17.

14. Sjogren U, Fidgor D, Spangberg L, Sundqvist G. The antimicrobial effect of calcium hydroxide as a short- term intracanal dressing. Int J Endod 1991; 24(1):19, 25.

15. Baron EJ, Peterson LR, Finegold SM. Bailey and Scott's diagnostic microbiology. $9^{\text {th }}$ ed. Toronto: CV Mosby; 1994. p. 342-5.

16. Wistreich GA, Lechtman MD. Laboratory exercises in microbiology. Antibiotic sensitivity testing method. Third edition. London: Glencoe Publishing Co, Inc; 1980. p. 234-7.

17. Morrier JJ, Benay G, Hortman C. Antimicrobial activity of calcium hydroxide dental cements. An in vitro study. J Endod 2003; 29(1):51-53.

18. Siqueira JF, Uzeda M. Intracanal medicaments: evaluation of the antibacterial effect of chlorhexidine, metronidazole and calcium hydroxide associate with three vehicle. J Endod 1997; 23(3):167-9.

19. Di Fiore PM, Peter D, Setterstrom JA. The antibacterial effects of calcium hydroxide apexification pastas on Streptococcus sanguis. J Oral Surg 1983; 55 (1):91-93.

20. Gomes BP, Ferraz CC, Garrido FD. Microbial susceptibility to calcium hydroxide pastes and their vehicle. J Endod 2003; 29(11):758-61.

21. Oztan MD, Yilmaz S, Kalayci A, Zaimoglu L. A comparison of the in vitro cytotoxicity of two root canal sealer. J of Oral Rehab 2003 30:426-9.

22. Widodo T. Paradigma baru pada perawatan endodontik. Kumpulan naskah seminar sehari tema ramah perlakuan pada jaringan gigi, IKORGI; 2000. p. 2, 6-7.

23. Barbosa CAM, Goncalves RB. Evaluation of antibacterial activities of calcium hydroxide, chlorhexidine, and camphorated paramonochlorophenol as intracanal medicament. Clinical and laboratories Study. J Endod 1997; 23(5):297-9.

24. Walton, Torabinejad. Pembersihan dan pembentukan saluran akar. In: Prinsip dan praktik ilmu endodontik. Sumawinata N, Nursasongko B, editor. Jakarta: Penerbit Buku Kedokteran EGC; 1998. p. 295-8.

25. Clement DJ. Medical center. Available at: endodontics.mcendo@ flash net. Accessed April 29, 2000.

26. Spangberg LSW. Instrumen, materials and devise. In: Cohen S, Burns RE, editors. Pathways of the pulp. $2^{\text {nd }}$ ed. St Louis: The CV Mosby Co; 1998. p. 476. 